East Tennessee State University

Digital Commons@ East Tennessee State University

ETSU Faculty Works

Faculty Works

6-1-2014

\title{
Surface-Soil Properties of Alder Balds with Respect to Grassy and Rhododendron Balds on Roan Mountain, North Carolina_-Tennessee
}

James T.Donaldson

East Tennessee State University, donaldsj@etsu.edu

Zachary C. Dinkins

East Tennessee State University

Foster Levy

East Tennessee State University, levyf@etsu.edu

Arpita Nandi

East Tennessee State University, nandi@etsu.edu

Follow this and additional works at: https://dc.etsu.edu/etsu-works

Part of the Plant Biology Commons, and the Plant Pathology Commons

\section{Citation Information}

Donaldson, James T.; Dinkins, Zachary C.; Levy, Foster; and Nandi, Arpita. 2014. Surface-Soil Properties of Alder Balds with Respect to Grassy and Rhododendron Balds on Roan Mountain, North Carolina-Tennessee. Southeastern Naturalist. Vol.13(2). 377-395.

https://doi.org/10.1656/058.013.0218 ISSN: 1528-7092

This Article is brought to you for free and open access by the Faculty Works at Digital Commons @ East Tennessee State University. It has been accepted for inclusion in ETSU Faculty Works by an authorized administrator of Digital Commons @ East Tennessee State University. For more information, please contact digilib@etsu.edu. 


\section{Surface-Soil Properties of Alder Balds with Respect to Grassy and Rhododendron Balds on Roan Mountain, North Carolina_-Tennessee}

\section{Copyright Statement}

Copyright of Southeastern Naturalist is the property of Eagle Hill Institute. This document was published with permission from the journal. It was originally published in the Southeastern Naturalist. 


\title{
Surface-soil Properties of Alder Balds with respect to Grassy and Rhododendron Balds on Roan Mountain, North Carolina-Tennessee
}

\author{
James T. Donaldson ${ }^{1}$, Zachary C. Dinkins ${ }^{2}$, Foster Levy ${ }^{1}$, and Arpita Nandi²,*
}

\begin{abstract}
We analyzed soils in Alder Bald, Grassy Bald, and Rhododendron Bald communities on Roan Mountain to infer the influence of vegetation on soil and to help guide management strategies. In all vegetation types, soils were acid $(\mathrm{pH}=4-5)$ sandy loams. We found vegetation-associated differences for organic content, cation exchange capacity, acidity, two plant macronutrients $(\mathrm{K}, \mathrm{Mg})$, and three cations ( $\mathrm{Fe}, \mathrm{Na}, \mathrm{Zn})$. We predicted that nitrogen compounds would be highest in the Alder Bald because Alnus viridis ssp. crispa (Green Alder) can harbor nitrogen-fixing bacteria. Organic content was highest at the alderbald sites, ammonium was similar among vegetation types, and nitrate was high at only some sample sites. The unique soil properties of the Alder Bald community, its likely role in primary succession, and its documentation as a long-standing community type on Roan Mountain suggest that management should be directed towards its conservation.
\end{abstract}

\section{Introduction}

Several high-elevation areas of the Roan Mountain massif of the southern Appalachian Mountains support grassy balds, a grassland ecosystem that shares characteristics with temperate alpine balds of the northeastern United States and Canada (Brown 1941, Dalton and Naylor 1975, Mark 1958). Although some highelevation open areas are of anthropogenic origin, the term southern Appalachian bald is more properly reserved for naturally occurring treeless areas below climatic tree-line on well-drained sites not otherwise dominated by rock (Mark 1958, Schafale 2012). These balds are unusual in their occurrence at an elevation below a natural tree-line and on sites with soils suitable for the establishment of a closedcanopy forest (Cogbill et al. 1997). Instead, grassy balds are dominated by native sedges and grasses interspersed with shrubs and forbs, including endemic species and species geographically disjunct from their main ranges in northern North America (Brown 1941, Mark 1958, NatureServe 2013, Schafale 2012).

Widespread encroachment of balds by native woody species, a progressively accelerating process over the past century, has greatly reduced the size of the balds and threatened the persistence of this ecosystem (Donaldson 2009; Donaldson et al. 2007, 2009; Powell 2011). A localized plant community known as the Southern Appalachian Alder Bald (hereafter referred to as Alder Bald), occurs within the Roan Mountain balds system (Jennings e al. 2009, NatureServe 2013). This community type is endemic to Roan Mountain and is dominated by Alnus viridis

\footnotetext{
${ }^{1}$ East Tennessee State University, Department of Biological Sciences, Johnson City, TN 37614. ${ }^{2}$ East Tennessee State University, Department of Geosciences, Johnson City, TN 37614. *Corresponding author - nandi@etsu.edu.
}

Manuscript Editor: Julia Cherry 
(Villars) Lamarck and De Candolle ssp. crispa (Aiton) Turrill (Green Alder ) (Betulaceae), an alpine shrub (Cogbill et al. 1997), and Carex pensylvanica Lamarck (Pennsylvania Sedge) (taxonomy follows Weakley 2012). Some hypothesize that Green Alder, including Alnus viridis (Villars) Lamarck \& De Candolle ssp. viridis (European Green Alder), drives the loss of grasslands through secondary succession (Anthelme et al. 2002). Others believe that Green Alder causes little loss of Roan Mountain's subalpine grasslands because Green Alder is not currently establishing new plants from seedling recruitment, although persisting extant clones may be expanding through layering (Donaldson 2008, 2009, 2010a, 2010b, 2011, 2012; Donaldson et al. 2007, 2009). Both views recognize that Green Alder can play an important role in primary succession.

The Roan Mountain balds contain three additional globally rare bald types. Southern Appalachian Catawba Rosebay Heath Balds, hereafter referred to as Rhododendron Balds, are dominated by Rhododendron catawbiense Michaux (Catawba Rhododendron) and are characterized by absent to sparse herbaceous cover. Grassy Balds (Southern Grass Type) are strongly dominated by Danthonia compressa Austin ex Peck (Mountain Oat-grass) and diverse sedges. Rare and geographically disjunct species such as Sibbaldia tridentata (Aiton) Paule \& Soják (Three-toothed Cinquefoil), Packera schweinitziana (Nuttall) W.A. Weber \& Á. Löve (New England Ragwort), and Minuartia groenlandica (Retzius) Ostenfeld (Greenland Sandwort) may be present. Sedge-type grassy balds are dominated by Pennsylvania Sedge growing with mixed graminoids and forbs, but they are generally less diverse than Grassy Balds (NatureServe 2013). Alder Balds, sedge-type grassy balds, and Grassy Balds are ranked as critically imperiled (global rank 1), and Rhododendron Balds are ranked as imperiled (global rank 2) (NatureServe 2013, Schafale 2012).

\section{Nitrogen-fixation in Green Alder}

In part because few native leguminous species inhabit southern Appalachian balds, Green Alder may play a key role in nutrient cycling because it is one of the few non-legumes to form symbioses with nitrogen-fixing microorganisms. Nitrogen fixation in alders is mediated by symbiotic members of the Actinomycetales, Frankia, in root nodules (Pawlowski and Newton 2008). In the symbiosis, the plant supplies essential minerals and energy to the bacteria, and the bacteria fix atmospheric nitrogen $\left(\mathrm{N}_{2}\right)$ in the form of ammonium $\left(\mathrm{NH}_{4}\right)$ (Miller and Gardiner 2007). Nitrification by oxidation of ammonium to nitrate is mediated by Nitrosomona bacteria that convert $\mathrm{NH}_{4}$ to $\mathrm{NO}_{2}$ (nitrite) followed by conversion to $\mathrm{NO}_{3}$ (nitrate) by Nitrobacter bacteria. When $\mathrm{NH}_{4}$ is oxidized, hydrogen ions are released in the soil, an effect that contributes to reduced $\mathrm{pH}$ in soils associated with alders. In an alder-dominated area, $\mathrm{NH}_{4}$ is elevated soon after nitrogen fixation, but it is readily converted to $\mathrm{NO}_{3}$. Hence, in alder-dominated sites, it is common to observe higher $\mathrm{NO}_{3}$ relative to $\mathrm{NH}_{4}$ (Anderson et al. 2004, Crocker and Major 1955, Gentili and Huss-Danell 2003, Knops et al. 2002, Mitchell 1968).

Few studies have examined the soil-vegetation interaction of the disjunct Green Alder population on Roan Mountain or the impacts of alders on soils in 
historically unglaciated areas (Brown 1941, Dalton and Naylor 1975). However, limited observations of soils associated with alders on Roan Mountain revealed lower levels of soil nitrogen compared to a control area (Dalton and Naylor 1975). This unanticipated result was attributed to rapid uptake by roots; hence the soil was nitrogen-depleted. In these studies, total nitrogen in soil was analyzed rather than nitrogen compounds specific to nitrogen fixation and uptake- $-\mathrm{NH}_{4}$ and $\mathrm{NO}_{3}$ (Martin et al. 2003).

Because bald habitats and some populations of the rare and disjunct species associated with them are declining (Donaldson et al. 2009, NaturerServe 2013), intensive Grassy Bald-restoration efforts have been implemented over the past 20 years. Management actions to maintain and restore the balds include mowing large tracts, mechanical weed removal, and the seasonal introduction of goats as browsers (Burley et al. 2006; Donaldson 2008, 2009, 2010a, 2010b, 2011, 2012; Donaldson et al. 2009; Weigl and Knowles 1999). Aggressive Grassy Bald-restoration efforts may have negative effects on Alder Bald communities and on the population of Green Alder, a species listed as rare in North Carolina and Tennessee (Brown 1941; Crabtree 2012; Gadd and Finnegan 2012; NatureServe 2013; Schafale 2012; USDA 1991, 2004). If dominant plant species on balds, particularly Green Alder, influence soils that in turn influence vegetation, then assessments of the impacts of management approaches should be examined before further widespread restoration is undertaken.

With bald habitats potentially threatened by both natural and anthropogenic factors, it is imperative that conservation efforts be evaluated and guided with an understanding of the impact of different vegetation types on soil ecology. To examine vegetation-related soil differences, we investigated physical and chemical properties of surface soils under the canopies of three different vegetation types on Roan Mountain balds: Alder Bald, Grassy Bald, and Rhododendron Bald. We hypothesized that Green Alder exerts an influence on surrounding soil properties of Roan Mountain balds. Specifically, we expected Green Alder leaf-litter to lower soil $\mathrm{pH}$ but not necessarily to levels below levels found under rhododendron thickets on Roan Mountain. We expected differences in soil structure because Green Alder has been shown to decrease bulk density (Chapin et al. 1994, Crocker and Major 1955), and we further expected soils associated with Green Alder to show the highest levels of the nitrogen-bearing compounds, $\mathrm{NH}_{4}$ and $\mathrm{NO}_{3}$, which are byproducts of nitrogen fixation and nitrification.

\section{Field-site Description}

We conducted our study on Roan Mountain's western balds in the area between Jane Bald $\left(36^{\circ} 6^{\prime} 21.79^{\prime \prime} \mathrm{N}, 8^{\circ} 5^{\prime} 36.26^{\prime \prime} \mathrm{W}\right)$ and Grassy Ridge $\left(36^{\circ} 6^{\prime} 21.79^{\prime \prime} \mathrm{N}\right.$, $82^{\circ} 5^{\prime} 14.63^{\prime \prime} \mathrm{W}$ ) (Fig. 1). The sample area was confined within a $0.6-\mathrm{km}$-long corridor on slopes greater than $20 \%\left(11.3^{\circ}\right)$ at elevations of $1745-1768 \mathrm{~m}(5720-5800 \mathrm{ft})$ with a southern exposure. The underlying bedrock was chiefly comprised of three rock formations: Roan gneiss, Cranberry granite, and Bakersville gabbro (Rodgers 1953). The majority of the soils in the study area belonged to the Wayah-Brunton complex 
soil series (WaE-Tennessee, and WyD-North Carolina), which are well-drained and generally found on mountaintops with slopes ranging from $15 \%$ to $30 \%\left(8.5^{\circ}-16.7^{\circ}\right)$. A typical soil profile of the Wayah-Brunton complex consists of $0-45.7 \mathrm{~cm}$ (18 in) of gravelly sandy loam overlying $45.7-76.2 \mathrm{~cm}$ (18-30 in) of gravelly loam on top of 76.2-203.2 cm (30-80 in) of unweathered, metamorphic bedrock. The average annual rainfall on the balds is $160.1 \mathrm{~cm}$ (63.0 in), the average snowfall is $141.5 \mathrm{~cm}$

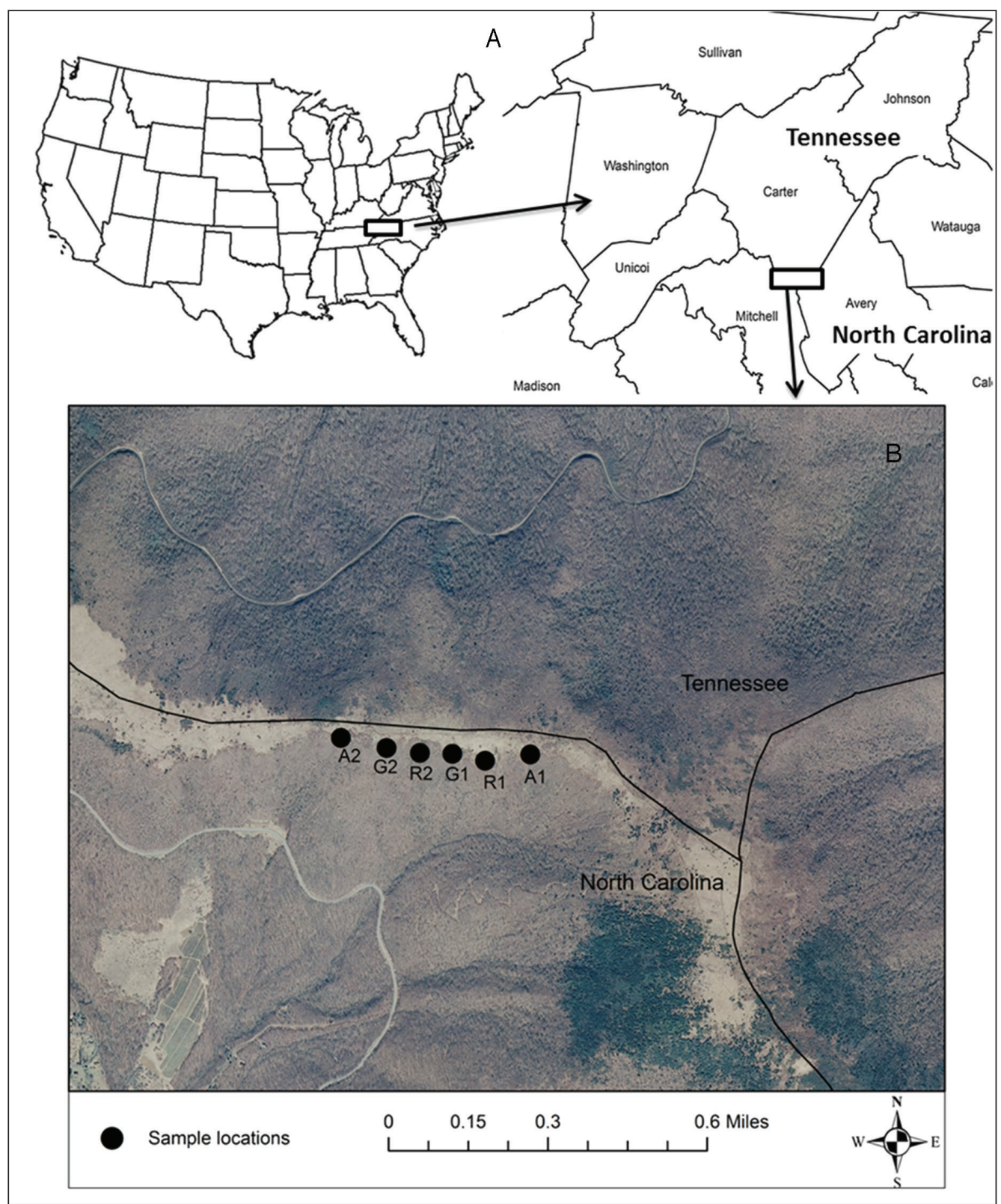

Figure 1. (A) Map showing the location of the study area in the saddle between Jane Bald (west) and Grassy Ridge (east); (B) aerial image showing where samples were collected from Alder Bald (A1, A2), Grassy Bald (G1, G2), and Rhododendron Bald (R1, R2). 
(55.7 in), and temperatures are generally about $1.7^{\circ} \mathrm{C}\left(35^{\circ} \mathrm{F}\right)$ in the winter and range from $10^{\circ} \mathrm{C}$ to $15.5^{\circ} \mathrm{C}\left(50\right.$ to $\left.60^{\circ} \mathrm{F}\right)$ in summer (NCCRONOS 2013).

Soils on the balds are acidic (USDA 2013). Historically, the low $\mathrm{pH}$ in the Blue Ridge physiographic province has been attributed to acidic bedrock (Pittillo et al. 1998) often overlain by vegetation yielding acid leaf-litter that influences soil development (Cain 1931, Horton et al. 2009, White et al. 2001, Wurzburger and Hendrick 2007). Further, Picea rubens Sarg. (Red Spruce)-Abies fraseri (Pursh) Poir. (Fraser Fir) forests, where leaf-litter is acidic, cover extensive areas at the highest elevations of the Southern Appalachians, specifically, above 1700 $\mathrm{m}$ on Roan Mountain. Moreover, with the rise of heavy industry in the eastern US, more-recent reductions in $\mathrm{pH}$ have been attributed to atmospheric deposition of sulfur dioxide, carbon dioxide, and nitrogen dioxide gases generated from the emissions of burning fossil fuels (Stanitski 2000).

A comparison of recent (2007) and historical (1926-1937) photographs shows that Alder Balds on Roan Mountain are relatively stable, and occupy similar locations and similar extent on Roan Mountain's western balds (Brown 1941, Donaldson et al. 2007, Wells 1937). Mean cover of Green Alder in the Alder Bald community was $65 \%$, with 0.9-1.2 m mean stem-height (Brown 1941). The Grassy Bald community has declined in extent, but examples were present where we collected our samples. The Rhododendron Bald community has generally increased in extent, but was either absent or of lesser extent at the sample sites. We collected samples in areas where the characteristic vegetation type covered at least 0.5 ha for the Alder Bald, 1 ha for the Grassy Bald, and 0.015 to 0.15 ha for the Rhododendron Bald. While the entire Roan Mountain massif was subject to intensive grazing from the 1830s until the 1950s (Bauer 2011, Donaldson et al. 2009), our sample sites were located in areas that had received minimal management over the past two decades, i.e., in areas where mowing and domestic grazing and browsing have been absent. We selected our sample sites based on the presence of undisturbed soil in areas with a minimal possibility of unearthing archeological remains (J. Franklin, East Tennessee State University, Johnson City, TN, pers. comm.). Within these constraints, we chose our sample sites randomly.

\section{Methods}

\section{Sample collection}

To test the effect of Green Alder on soils, and to examine vegetation-related differences, we collected soils from two independent locations within each vegetation type (designated A1, A2; G1, G2; and R1, R2, where A, G, and R designate Alder, Grassy, and Rhododendron Balds, respectively, Fig. 1). Location A1 had alder shrubs averaging $1-1.5 \mathrm{~m}$ tall $\mathrm{x} 1-1.5 \mathrm{~m}$ wide with average spacing of 1-2 m. The gaps were dominated by Rubus canadensis L. (Canada Blackberry) and graminoids. We estimated soil depth using a $15-\mathrm{cm}$ probe. Location A2 had larger Green Alder shrubs that averaged $>1.5 \mathrm{~m}$ high x $1.5-2 \mathrm{~m}$ or more wide, with close spacing (branch tips confluent); gaps $<1 \mathrm{~m}$ wide). The gaps, which we avoided during sampling, were dominated by Canada Blackberry and graminoids 
with scattered Catawba Rhododendron. Locations G1 and G2 were similar and occupied the same large expanse of Grassy Bald habitat. Location R1 was a narrow Rhododendron Bald $\approx 0.015$ ha in extent, and $\mathrm{R} 2$ was much larger and occupied $\approx 0.15$ ha.

Within each location, we took 5 soil samples for a total of 30 samples. We selected sample sites randomly as long as they were located a minimum of $2 \mathrm{~m}$ from any other site and from community edges. We removed organic cover - up to 15 $\mathrm{cm}$ at some sites - to reach the topsoil. We used sterile, cylindrical, plastic containers attached to a hand-held split-core soil-sampler to extract soil-core samples (5 $\mathrm{cm} \times 15 \mathrm{~cm}$ ) that weighed $\approx 500 \mathrm{~g}$ each. For supplementary soil analysis, we used a trowel to collect additional bulk soil samples of $\approx 300 \mathrm{~g}$ each. We collected all samples in early December 2011, after leaf-fall and when soil microbiological activity was low. We chose this time to reduce the possibility of additional nitrogen releases from decomposed soil organic matter. Thus, the design consisted of three vegetation types, two sample locations within each vegetation type, and five sites from which samples were taken within each location.

\section{Soil analysis}

Prior to analysis, we air-dried all samples and ground them to pass through a 2-mm sieve. Soil physical properties analyzed included particle-size distribution (PSD), bulk density, and moisture content. Soil chemical analysis included assays for $\mathrm{pH}$, cation-exchange capacity (CEC), organic content, and plant macro- and micronutrient concentrations. Z.C. Dinkins performed the physical property analyses at the East Tennessee State University Geosciences Laboratory (Johnson City, TN). Brookside Laboratories, Inc. (New Bremen, $\mathrm{OH}$ ) conducted the chemical analyses.

PSD determination was performed using sieve and hydrometer analysis to determine the gradation (distribution of soil particles by size) within a given sample following the USDA 3A1 method (Burt 2004) with the results visualized on USDA soil-texture triangles. Bulk density was calculated as the ratio of the weight of each core sample to its volume (Blake and Hartge 1986), and moisture content was measured using the ASTM D 4643 method (ASTM 2000).

Chemical analyses were carried out using the following methods: cation exchange capacity via the Ross (1995) method; $\mathrm{pH}\left(1: 1\right.$ in $\left.\mathrm{H}_{2} \mathrm{O}\right)$ used the McLean (1982) method; SMP/Sikora buffer $\mathrm{pH}$ followed the Shoemaker, McLean, and Pratt (1961) method; and organic matter (loss on ignition at $360{ }^{\circ} \mathrm{C}$ ) used the Schulte and Hopkins (1996) method. Concentrations of the plant macro- and micronutrients $\mathrm{Al}, \mathrm{B}, \mathrm{Ca}, \mathrm{Cu}, \mathrm{Fe}, \mathrm{K}, \mathrm{Mg}, \mathrm{Mn}, \mathrm{Na}, \mathrm{P}, \mathrm{S}$, and $\mathrm{Zn}$ were determined using the Mehlich (1984) method. We calculated the estimated nitrogen release according to the computed estimate for annual release of nitrogen through organic matter (Pastor and Binkley 1998). We based our calculations on the loss due to ignition. We estimated available nitrogen as $\mathrm{NO}_{3}$ and $\mathrm{NH}_{4}$ using the Dahnke (1990) method.

\section{Statistical analysis}

We used SAS v9.2 (SAS Institute 2002) for our statistical analyses. For each soil property, we analyzed differences in a mixed-model nested ANOVA using the GLM 
procedure, with the random factor, soil location, nested within the fixed factor, vegetation type. To test the significance of differences among vegetation types, we constructed $F$-ratios using the mean squares for locations within vegetation types as the denominators and the mean squares for vegetation types as the numerators and conducted Tukey's significant difference tests to determine which vegetation type means differed. We used the Nested procedure to partition the variance. We computed correlations between different soil properties using the Pearson correlation coefficient, and tested for significance using $t$-tests. We quantified estimated nitrogen release from organics as either less than or more than $146 \mathrm{~kg} / \mathrm{ha}$. Hence, we conducted comparisons among vegetation types on the frequencies of this twostate variable using Fisher's exact test; $P<0.05$ was considered significant, and $0.05<P<0.07$ was considered marginally significant.

\section{Results}

\section{Physical properties}

Results from our soil probes at A1 showed that soils were typically thin $(<15$ $\mathrm{cm}$ ) and covered by overlying boulders that facilitated rapid drainage. The soils at A 2 were deeper compared to A1, with $>75 \%$ of the probes encountering no rock. The soil texture throughout the study area was sandy loam to loam and sandy clay loam, where sand was the dominant particle size in each location. The sand component tended to be higher in Rhododendron Bald soils and lower in Alder Bald soils, and soils on the Grassy Balds had higher clay content (Fig. 2). There were no significant differences for bulk density or moisture content among locations (Table 1). Soils were acid in the entire study area, as evidenced by the low SMP and $\mathrm{pH}$ (range $=4-5$ ); both SMP and $\mathrm{pH}$ were highest in the Rhododendron Bald soils and lowest in the Alder Bald soils. CEC and organic content also differed significantly and marginally significantly, respectively, among vegetation types; values were highest in alder-bald soils and lowest in Grassy Bald soils (Table 1). CEC and organic content were strongly correlated $(r=+0.77, P<0.0001)$, but CEC showed an exceptionally strong negative correlation with soil texture $(r=$ $-0.99, P<0.0001)$ and a significant negative correlation with soil $\mathrm{pH}(r=-0.54$, $P=0.002)$.

\section{Chemical Properties}

Assays for the three primary plant macronutrients showed that potassium concentrations differed significantly among vegetation types; with the lowest concentrations in the Alder Bald type. There were significant differences in phosphorous concentrations among sample locations within vegetation types; the largest range and highest mean concentrations were for samples from the Alder Bald community (Table 1). The number of sample sites with high levles of nitrogen release from organic matter $(>146 \mathrm{~kg} / \mathrm{ha})$ was significantly greater in Alder Balds ( 9 of 10 sites) compared to the Grassy and Rhododendron Balds (2 of 10 sites each) $(P<$ 0.01 ; data not shown). Nitrate concentration varied significantly among sampling locations, most notably in the Alder Bald, where 3 sample locations had nitrate 
concentrations $>25 \mathrm{ppm}$ and the remaining 7 locations had concentrations $<20 \mathrm{ppm}$ (Table 2). Five Grassy Bald locations had nitrate concentrations of 10-20 ppm and 5 had concentrations $<10 \mathrm{ppm}$, whereas in the Rhododendron Bald, concentrations at all locations were $<10 \mathrm{ppm}$. Although differences in nitrate concentrations among vegetation types were not significant, those differences explained $42 \%$ of the variation in the entire sample, a proportion that exceeded the variation explained by differences among sample locations (38\%); the latter were significant (Tables 1,2). The $\mathrm{pH}$-reducing effect of nitrification resulted in a strong negative correlation of $\mathrm{pH}$ and nitrate $(r=0.87, P<0.0001)$. In contrast, ammonium showed no significant differences, either among vegetation types or among sample locations within types (Tables 1,2). Magnesium concentrations in our soil samples differed significantly among vegetation types; the highest concentration was in samples from the Rhododendron Bald type. Sulfur concentrations differed among sample locations within vegetation types, and there were no significant differences in calcium concentrations among sites or between types (Table 1).

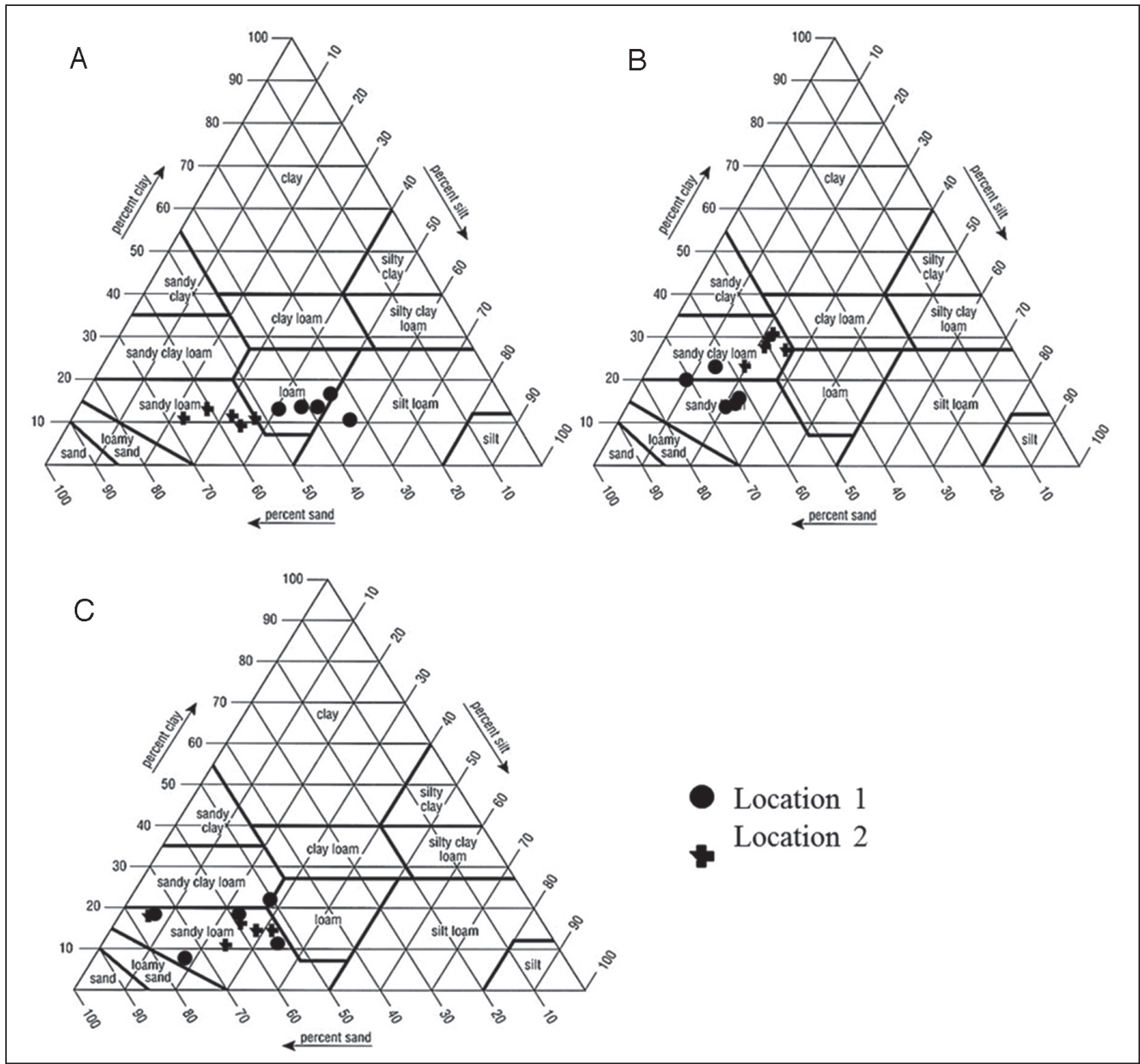

Figure 2. Particle-size distribution of soils in the alder bald (A), grassy bald (B), and rhododendron bald $(\mathrm{C})$. 


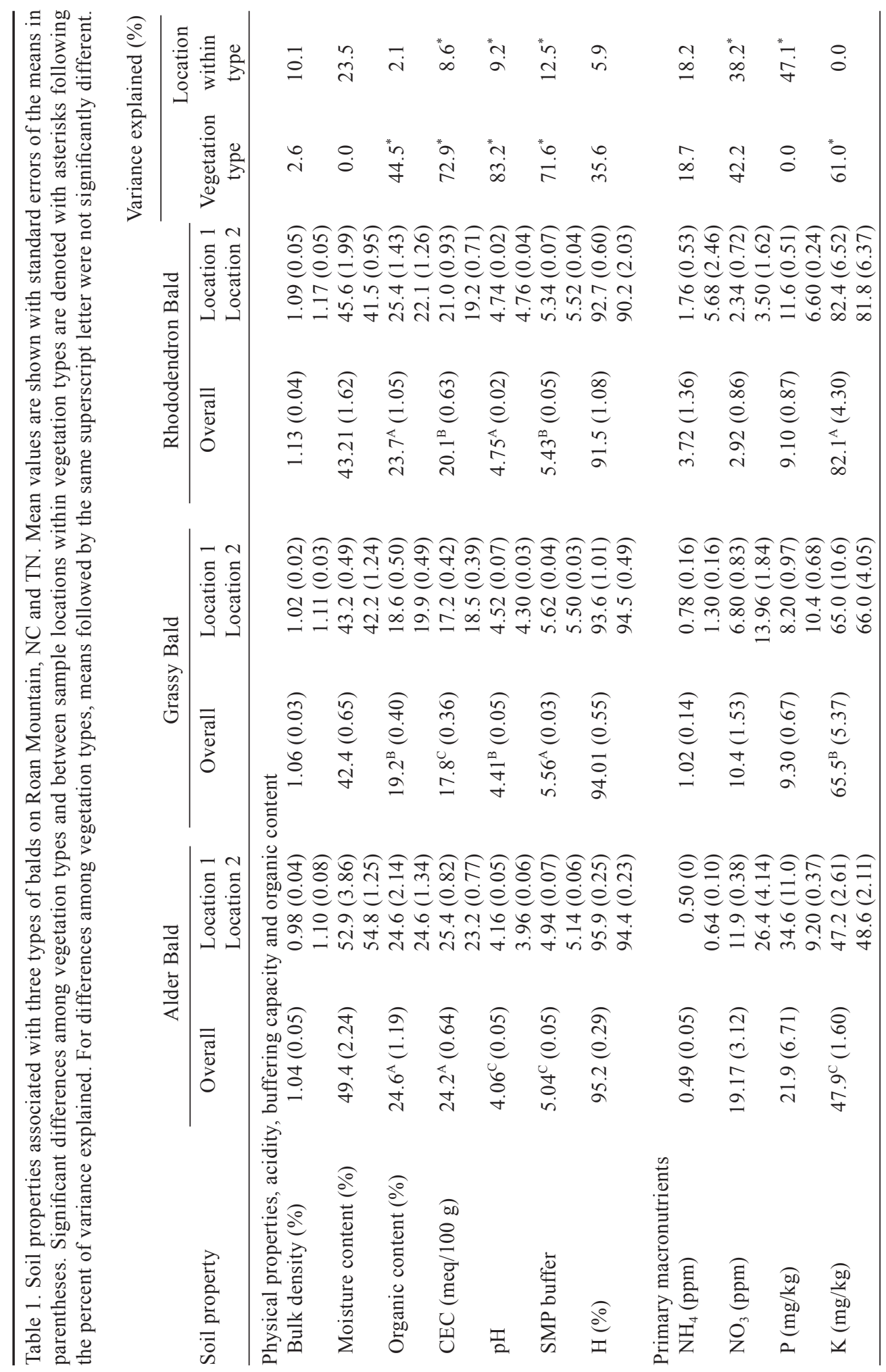


J.. Donaldson, Z.C. Dinkins, F. Levy, and A. Nandi

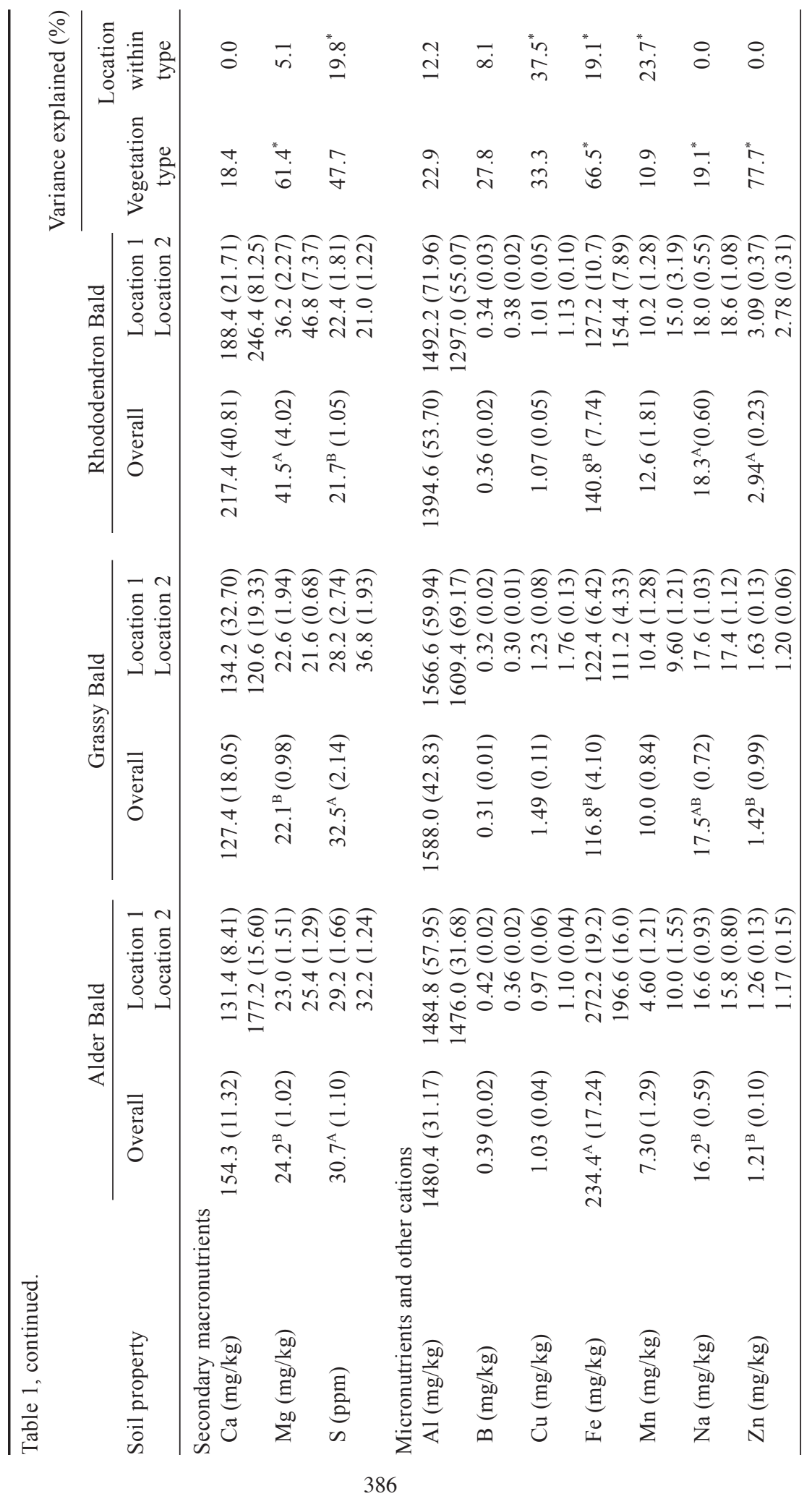


The results from our soil-micronutrient analyses showed significant differences among vegetation types for zinc, and among sample locations within vegetation types for copper and manganese. Iron concentrations were significantly different among vegetation types and among sample locations within type; there were no significant differences for boron (Table 1). Concentrations of 5 of the cations examined had significant positive correlations with $\mathrm{pH}(\mathrm{Mg}: r=0.53, P<0.01$; K: $r=0.741, P<0.0001$; Na: $r=0.41, P=0.02 ; \mathrm{Mn}: r=0.37, P=0.04 ; \mathrm{Zn}: r=0.71$, $P<0.0001)$.

For all but one of the soil properties showing significant differences among vegetation types (CEC, SMP, $\mathrm{pH}, \mathrm{Mg}, \mathrm{K}, \mathrm{Fe}, \mathrm{Zn}$ ), those differences explained $61-82 \%$ of the total variation among samples (Table 1). For Na, differences among vegetation types explained only $19 \%$ of the variation.

Table 2. Soil ammonium $\left(\mathrm{NH}_{4}\right)$ and nitrate $\left(\mathrm{NO}_{3}\right)$ concentrations (ppm) at each sample location and site within Alder Balds, Grassy Balds, and Rhododendron Balds.

\begin{tabular}{|c|c|c|c|c|}
\hline Vegetation type & Location & Site & $\mathrm{NH}_{4}$ & $\mathrm{NO}_{3}$ \\
\hline \multirow[t]{10}{*}{ Alder Bald } & 1 & 1 & $<0.5$ & 11.2 \\
\hline & & 2 & $<0.5$ & 13.3 \\
\hline & & 3 & $<0.5$ & 11.9 \\
\hline & & 4 & $<0.5$ & 11.9 \\
\hline & & 5 & $<0.5$ & 11.2 \\
\hline & 2 & 1 & $<0.5$ & 18.2 \\
\hline & & 2 & 1.0 & 15.2 \\
\hline & & 3 & $<0.5$ & 36.6 \\
\hline & & 4 & $<0.5$ & 29.9 \\
\hline & & 5 & 0.7 & 32.3 \\
\hline \multirow[t]{10}{*}{ Grassy Bald } & 1 & 1 & 1.0 & 7.5 \\
\hline & & 2 & $<0.5$ & 3.8 \\
\hline & & 3 & $<0.5$ & 6.3 \\
\hline & & 4 & 0.6 & 8.0 \\
\hline & & 5 & 1.3 & 8.4 \\
\hline & 2 & 1 & 1.9 & 13.4 \\
\hline & & 2 & 1.2 & 10.6 \\
\hline & & 3 & 1.1 & 20.3 \\
\hline & & 4 & 1.0 & 15.3 \\
\hline & & 5 & 1.3 & 10.2 \\
\hline \multirow[t]{10}{*}{ Rhododendron Bald } & 1 & 1 & 1.9 & 4.8 \\
\hline & & 2 & 1.3 & 1.1 \\
\hline & & 3 & $<0.5$ & 0.9 \\
\hline & & 4 & 3.7 & 1.9 \\
\hline & & 5 & 1.4 & 3.0 \\
\hline & 2 & 1 & $<0.5$ & 0.6 \\
\hline & & 2 & 2.1 & 1.0 \\
\hline & & 3 & 8.6 & 6.1 \\
\hline & & 4 & 13.9 & 8.6 \\
\hline & & 5 & 3.3 & 1.2 \\
\hline
\end{tabular}




\section{Discussion}

\section{Vegetation influences on soil}

The sandy loam soils that characterized the entire study area differed only slightly in particle-size distribution between vegetation types. We anticipated that all of the soils at our study sites would be identified as loams because we analyzed only the topsoil, and in this high-rainfall region a high proportion of the finer silt and clay minerals leach into the lower soil horizons. Although we expected to detect differences in soil structure because alder has been shown to decrease bulk density (Chapin et al. 1994, Crocker and Major 1955), we found no significant differences in bulk density among vegetation types at our sites on Roan Mountain.

Despite similarities in particle-size distribution, soils from each of the types of balds had a unique suite of properties. Notably, several soil characteristics showed significant differences among vegetation types. Those differences explained a large proportion of the variation among samples and suggest that vegetation influences soils. For example, soils from the Alder Bald sites were highest in organic matter and CEC, and had high exchangeable nitrogen, and some of those sample sites had high nitrate levels, but Alder Bald soils were lowest in $\mathrm{pH}$, potassium, and manganese.

Alder has been shown to have an acidifying effect on soils (Anderson et al. 2004, 2009; Bormann and Sidle 1990; Chapin et al. 1994; Crocker and Major 1955; Densmore 2005; Mitchell and Ruess 2009; Rhoades et al. 2001). Although soils throughout the study area were acidic, Alder Bald soils had significantly lower $\mathrm{pH}$ and SMP values compared to the two other vegetation types. An unexpected result was that $\mathrm{pH}$ was highest in soils from the Rhododendron Bald sites. Instead, we expected that Grassy Bald soils would have highest $\mathrm{pH}$ because grasslands throughout the Great Plains tend toward neutral and basic pH (Brady and Weil 2002). Compared to the Great Plains, the relatively low soil $\mathrm{pH}$ of the Grassy Bald soils in our study might be attributed to acidic parent rock and codominance of sedges vs. dominance by sedges rather than grasses. Moreover, soils in grasslands of the Great Plains tend to be deep and organically rich. High CEC is expected in organically rich soil as the organic matter breaks down to release acids that bind cations (Johnson 2002). As expected, CEC and organic content were strongly correlated, and both were highest at the Alder Bald sites and lowest in the Grassy Bald sites. The low CEC and organic content of the Grassy Bald soils may reflect the rocky and relatively shallow soils found there. The apparent younger age based on historic photographs and smaller size of the sampled Rhododendron Balds might explain why this community type had the highest $\mathrm{pH}$ of the three bald types.

We also expected Alder Bald soils to show the highest levels of the nitrogenbearing compounds, $\mathrm{NH}_{4}$ and $\mathrm{NO}_{3}$, the products of nitrogen fixation and nitrification, respectively (Anderson et al. 2004, Crocker and Major 1955, Gentili and Huss-Danell 2003, Knops et al. 2002, Mitchell 1968). We found relatively high $\mathrm{NO}_{3}$ levels in Alder Bald soils, but the concentration varied significantly among sample locations (Table 2). Differential leaching, differences in soil depth, and differential nodulation among sample locations may have caused these differences. For example, we found that bedrock was much closer to the surface at one of the 
Alder Bald locations than at the others. Further, it has been shown that variability in nodulation capacity of Frankia is related to stand length, width, age, and stem density and these factors distinguish Alder Bald locations 1 and 2 (Anderson et al. 2009, Martin et al. 2003, Sampò et al, 1997). Although differences in $\mathrm{NH}_{4}$ concentration were not significantly different among vegetation types, $\mathrm{NH}_{4}$ was highest in the soils from Rhododendron Balds, an observation that suggests the $\mathrm{NH}_{4}$ in those soils was not readily converted to $\mathrm{NO}_{3}$. A low rate of nitrification in rhododendrondominated sites may be attributed to a low population of nitrifying soil bacteria (Vitousek et al. 1982). Considering the leaching effects of the wet environment, the atmospheric nitrogen fixed by the alder-Frankia symbiosis may be of great longterm significance for soil- and plant-community development on Roan Mountain.

Phosphorus (P) also showed significant differences among locations within vegetation types, an effect that could be attributed to an elevated $\mathrm{P}$ concentration at a single sample-site in Alder Bald location 1. There is no simple explanation for the aberrant value, but perhaps that sample was taken where bone or antler of a large vertebrate had recently decomposed.

In summary, although the vegetation impact on soil fertility may vary depending upon the nutrient, differences in vegetation clearly impact soil characteristics, and these vegetation-mediated differences are likely a factor in maintaining diversity in the bald ecosystem.

\section{Southern Appalachian Alder Bald}

The origins of Southern Appalachian Grassy Balds have been debated, but there is clear evidence that Roan Mountain's western balds (Round Bald, Jane Bald, and Grassy Ridge) pre-date European settlement (Gray 1842, Mitchell 1839, Strother 1799). These balds have generally been considered examples of a natural plant community whose extent may have increased due to anthropogenic causes (Brown 1941, Mark 1958, NatureServe 2013, Schafale 2012). The Alder Bald community is strictly endemic to the Roan Mountain massif (Avery and Mitchell counties, NC, and Carter County, TN) where it occurs as sporadic patches interrupted by Grassy Bald and Rhododendron Bald occurrences on Roan Mountain's western balds (NatureServe 2013, Schafale 2012). Green Alder occurs nowhere else south of the last terminal moraine, and this population is $>480$ $\mathrm{km}$ disjunct from the nearest site in Pennsylvania and $>800 \mathrm{~km}$ disjunct from the main range of the species that reaches its southern limit in northern New England (Furlow1997, Wherry 1960).

Although Green Alder was noted on Roan Mountain prior to 1850 (Gray 1842), based on semi-quantitative historic accounts of the historic extent of the Alder Bald community (Brown 1941, Harshberger 1903) and on a comparison of historic and modern photographs (Brown 1941, Donaldson et al. 2007, Wells 1937), the area covered by the Alder Bald type has decreased by over $50 \%$ during the past century. Moreover, Catawba Rhododendron and Canada Blackberry have invaded much of the remaining Alder Bald area. Only an estimated $<50$ ha of high-quality, highdensity alder bald remains (J.T. Donaldson, pers. observ.). 


\section{Alder Bald ecological influence}

The potential role of Roan Mountain's Alder Bald community in primary succession and soil development has been underappreciated. Although local studies are few (Dalton and Naylor 1975), alder thickets have significant influences on ecological succession and soil development as documented in Europe with European Green Alder (Anthelme et al. 2002), and in Alaska with several alder taxa (Anderson et al. 2004, 2009; Bormann and Sidle 1990; Densmore 2005; Fastie 1995; Mitchell and Ruess 2009; Rhoades et al. 2001). For example, alder increases available nitrogen via fixation of atmospheric nitrogen and it accelerates nitrogen cycling. Anderson et al. $(2004,2009)$ found that alder-fixed nitrogen accounted for $60-70 \%$ of nitrogen accumulated over 200 years of primary succession. These effects on nitrogen availability can influence species composition and ecosystem structure, ecosystem function (net primary production, rates of succession), and landscape evolution; effects observed even at some distance from alder plants (Mitchell and Ruess 2009). For example, Densmore (2005) showed that nitrogen-fixation facilitated graminoid establishment during revegetation of placer-mine soils.

Alder's role in primary succession is limited by its life history, interspecific interactions, competitive inhibition, and landscape position (seed-source proximity/dispersal limitations) more than abiotic conditions (Chapin et al. 1994, Fastie 1995). To germinate, alder seeds need bare mineral soils and full sun (Anthelme et al. 2002, Chapin et al. 1994, Rhoades et al. 2001).

Changes in cover of European Green Alder following land disuse in subalpine grasslands of the western Alps led to the hypothesis that colonization of new areas was via seed (sexual reproduction) and persistence was through layering (vegetative reproduction) (Anthelme et al. 2002). Anthelme et al. (2002) attributed a lack of seedlings in well-established European Green Alder thickets to shading effects. Similarly, Donaldson (2008, 2010a, 2010b, 2011, 2012) also recorded a lack of Green Alder seedlings in Roan Mountain's Alder Balds as well as in all other study plots in the vicinity, but did observe evidence of layering. The closed canopies of Catawba Rhododendron and Canada Blackberry appear sufficient to prevent seedling establishment by the light-demanding Green Alder (Anthelme et al. 2002, Chapin et al. 1994), further indicating that Green Alder establishment preceded colonization by either of these species. Additionally, sites with bare mineral soil, which Green Alder seeds require to germinate and become established (Chapin et al. 1994, Rhoades et al. 2001), are uncommon, on Roan Mountain, at least away from the hiking trails. Thus, there is very little suitable habitat there for new Green Alder establishment through primary succession.

Several authors noted that alder thickets have a capacity for long persistence (Anderson et al. 2004, Chapin et al. 1994, Donaldson et al. 2007, Mitchell and Ruess 2009, NatureServe 2013, Rhoades et al. 2001), and Mitchell and Ruess (2009) suggest that they "may persist for decades, if not centuries". Further examination is needed to assess the capacity for long-term persistence of Alder Balds on Roan Mountain and to determine the rate, if any, of Alder Bald expansion into the Grassy Balds. 


\section{Management implications}

While acknowledging the Alder Bald community's rarity and affording it some federal protection due to its majority occurrence on National Forest land (USDA 1991, 2004), the ecological model upon which prior and current management is based seemingly overlooks Green Alder's role in primary succession. Instead, recent management plans implicitly place Alder Balds in secondary succession following Brown's (1941, Fig. 35) proposed ecological flow chart from bare rock, to rock mosses and lichens, to Polytrichum moss community, to Grassy Bald, to woody plant community, including Alder Bald, Rhododendron Bald, and spruce-fir forest (as well as hardwood forest types which were not included on the chart). With a succession scenario in which Alder Balds displace Grassy Balds, Grassy Bald restoration could be considered synonymous with alder-bald reduction or eradication. Similarly, Anthelme et al. (2002) considered the European Green Alder a threat to subalpine grasslands in the Alps and supported its reduction in favor of the grasslands. However, if the establishment requirements and soil-enhancing properties of the Alder Bald community are recognized and the alternative hypothesis that Alder Balds may have developed from primary succession can be supported, then the ecological assumptions regarding the role of the Alder Bald type in the bald ecosystem may be incorrect and management approaches misdirected.

Grassy Bald restoration typically begins from the areas most recently degraded by invasion of Catawba Rhododendron and Canada Blackberry along the current bald edge, and proceeds downslope toward the established tree line into progressively thicker, older, and taller woody plants. If managers target the upslope Green Alder under the assumption that it is displacing grassy-bald vegetation through secondary succession, then the Alder Bald community is removed from its upslope position at the same time that it is being lost to woody-plant invasion on the downslope tree-line edges. Rather, Grassy Bald management should consider that the Alder Bald community is rare, that Green Alder is a keystone species, and that Alder Bald decreases result from management to maintain grassy balds and from woody-plant invasion.

\section{Acknowledgments}

We thank the Friends of Roan Mountain, the Baatany Goat Project, the East Tennessee State University (ETSU) Departments of Biological Sciences and Geosciences, the ETSU Research Development Committee (RDC), and the ETSU Honors College for financial support; Dr. Jay Franklin for checking the site for archaeological significance; and the Cherokee and Pisgah National Forests for allowing us to conduct the study on federal land. The manuscript benefited from comments of anonymous reviewers.

\section{Literature Cited}

American Society for Testing and Materials (ASTM). 2000. Annual book of ASTM standards, Soil and Rock (1): D 420-D4914, American Society for Testing Materials, West Conshohocken, PA. 4.08:1000. 
Anderson, M.D., R.W. Ruess, and J.S. Mitchell. 2004. Estimating $\mathrm{N}_{2}$ fixation in two species of Alnus in interior Alaska using acetylene reduction and ${ }_{153} \mathrm{~N}_{2}$ uptake. Ecoscience 11:102-112.

Anderson, M.D., R.W. Ruess, D.D. Myrold, and D.L. Taylor. 2009. Host species and habitat effect nodulation by specific Frankia genotypes in two species of Alnus in interior Alaska. Oecologia 160:619-630.

Anthelme, F, L. Cornillon, and J-J. Brun. 2002. Secondary succession of Alnus viridis (Chaix) DC. in Vanoise National Park, France: Coexistence of sexual and vegetative strategies. Annals of Forestry Science 59:419-428.

Bauer, J. 2011. Roan Mountain: History of an Appalachian treasure. The History Press, Charleston, SC. 162 pp.

Blake, G.R., and K.H. Hartge. 1986. Bulk density. Pp. 363-375, In A. Klute (Ed.). Methods of Soil Analysis Part I: Physical and Mineralogical Methods. Soil Science Society of America, Book series 3. American Society of Agronomy, Madison, WI. 1358 pp.

Bormann, B.T., and R.C. Sidle. 1990. Changes in productivity and distribution of nutrients in a chronosequence at Glacier Bay National Park, Alaska. Ecology 78:561-578.

Brady, N., and R. Weil. 2002. The Nature and Properties of Soils, 13th Edition. Prentice Hall, Upper Saddle River, NJ. 960 pp.

Brown, D.M. 1941. Vegetation of Roan Mountain: A phytosociological and successional study. Ecological Monographs 11:61-97.

Burley, T., N. Schubert, J. Murray, J. Peine, and M. Thompson. 2006. NBII-SAIN FY05 Roan Mountain Project final report (final report version 8/30/06 version). US Geological Survey, Southern Appalachian Information Node, Knoxville, TN.

Burt, R. (Ed.). 2004. Soil survey laboratory methods manual. Soil survey investigation report \#42, version 4.0, November 2004. USDA, Natural Resources Conservation Service, Lincoln, NE. 700 pp.

Cain, S.A. 1931. Ecological studies of the vegetation of the Great Smoky Mountains of North Carolina and Tennessee. I. Soil reaction and plant distribution. Botanical Gazette 91:22-41.

Chapin, F.S. III, L.R. Walker, C.L. Fastie, and L.C. Sharman. 1994. Mechanisms of primary succession following deglaciation at Glacier Bay, Alaska. Ecological Monographs 64:149-175.

Cogbill, C.V., P.S. White, and S.K. Wiser. 1997. Predicting treeline elevation in the Southern Appalachians. Castanea 62:137-146.

Crabtree, T. 2012. Tennessee Natural Heritage Program rare plant list. Tennessee Department of Environment and Conservation, Nashville, TN.

Crocker, R.L., and J. Major. 1955. Soil development in relation to vegetation and surface age at Glacier Bay, Alaska. Journal of Ecology 43:427-448.

Dahnke, W.C. 1990. Testing soils for available nitrogen. Pp. 120-140, In R.L. Westerman (Ed.). Soil Testing and Plant Analysis. Soil Science Society of America, Book series 3, American Society of Agronomy, Madison, WI. 784 pp.

Dalton, D.A., and A.W. Naylor. 1975. Studies of nitrogen fixation by Alnus crispa. American Journal of Botany 62:76-80.

Densmore, R.V. 2005. Succession on subalpine placer mine spoil: Effects of revegetation with Alnus viridis, Alaska, USA. Arctic, Antarctic, and Alpine Research 37:297-303.

Donaldson, J.T. 2008. Baatany Goat Project 2008 final report. Unpublished report submitted to the US Forest Service and Appalachian Trail Conservancy. 10 pp. plus appendices.

Donaldson, J.T. 2009. Baatany in the balds. Appalachian Trail Journeys 54:11-15. 
Donaldson, J.T. 2010a. Baatany Goat Project 2009 final report. Unpublished report submitted to the US Forest Service and Appalachian Trail Conservancy. 8 pp. plus appendices.

Donaldson, J.T. 2010b. Baatany Goat Project 2010 final report. Unpublished report submitted to the US Forest Service and Appalachian Trail Conservancy. 14 pp. plus appendices.

Donaldson, J.T. 2011. Baatany Goat Project 2011 final report. Unpublished report submitted to the US Forest Service and Appalachian Trail Conservancy. 17 pp. plus appendices.

Donaldson, J.T. 2012. Baatany Goat Project 2012 final report. Unpublished report submitted to the US Forest Service and Appalachian Trail Conservancy. 16 pp. plus appendices.

Donaldson, J.T., C. Warden, and J. Bauer. 2007. A preliminary "then and now" look at $70+$ years of historic landscape photos from Roan Mountain, NC-TN (poster). P. 38, In Southern Appalachian Man and the Biosphere (SAMAB) (Ed.). $18^{\text {th }}$ Annual SAMAB Conference: Rising to the challenge of a new century, 22-24 October 2007, Carnegie Hotel, Johnson City, TN. 71 pp.

Donaldson, J.T., N. Schubert, and L.C. Huff. 2009. Management of grassy-bald communities in the Roan Highlands. P. 234, In J.S. Rentch and T.M. Schuler (Eds). 2010. Conference on the ecology and management of high-elevation forests in the central and southern Appalachian Mountains: Proceedings of a conference held at Snowshoe Mountain Resort, Slatyfork, WV, 14-15 May 2009. General Technical Report NRS-P-64. US Department of Agriculture, Forest Service, Northern Research Station, Newtown Square, PA. 242 pp.

Fastie, C.L. 1995. Causes and ecosystem consequences of multiple pathways of succession at Glacier Bay, Alaska. Ecology 76:1899-1916.

Furlow, J.J. 1997. Alnus. Pp. 509-516, In Flora of North America Editorial Committee (Eds). Flora of North America North of Mexico, Vol. 3. Oxford University Press, New York, NY. 616 pp.

Gadd, L., and J.T. Finnegan. 2012. Natural Heritage Program list of rare plant species of North Carolina. NC Department of Environment and Natural Resources, Raleigh, NC.

Gentili, F., and K. Huss-Danell. 2003. Local and systemic effects of phosphorus and nitrogen on nodulation and nodule function in Alnus incana. Journal of Experimental Botany $54: 2757-2767$.

Gray, A. 1842. Notes of a botanical excursion to the mountains of North Carolina and etc.; with some remarks of the botany of the higher Alleghany Mountains. American Journal of Science and Arts 42:1-49.

Harshberger, J. 1903. An ecologic study of the flora of mountainous North Carolina (concluded). Botanical Gazette 36:368-383.

Horton, J.L., B.D. Clinton, J.F. Walker, C.M. Beier, and E.T. Nilsen. 2009. Variation in soil and forest-floor characteristics along gradients of ericaceous, evergreen-shrub cover in the southern Appalachians. Castanea 74:340-352.

Jennings, M.D., D. Faber-Langendoen, O.L. Loucks, R.K. Peet, and D. Roberst. Sood. Standards for associations and alliances of the US National Vegetation Classification. Ecological Monographs 79:173-199.

Johnson, C.E. 2002. Cation-exchange properties of acid forest soils of the northeastern USA. European Journal of Soils Science 53:271-282.

Knops, M.H., K.L. Bradley, and D.A. Wedin. 2002. Mechanisms of plant-species impacts on ecosystem nitrogen-cycling. Ecology Letters 5:454-466.

Mark, A. 1958. The ecology of southern Appalachian grass balds. Ecological Monographs 28:293-336.

Martin, K.J., N.J. Posavatz, and D.D. Myrold. 2003. Nodulation potential of soils from Red Alder stands covering a wide age-range. Plant Soil 254:187-192. 
McLean, E.O. 1982. Soil pH and lime requirement. Pp. 199-223, In Miller and Keeney (Eds.) Methods of Soil Analysis: Chemical and Microbiological Properties, Agronomy 9 (2nd Edition), American Society of Agronomy and Soil Science Society of America, New York, NY.

Mehlich, A. 1984. Mehlich 3 soil-test extractant: A modification of Mehlich 2 extractant. Communications in Soil Science and Plant Analysis. 15:1409-1416.

Miller, R.W., and D.T. Gardiner. 2007. Soils in Our Environment, 11th Edition, Prentice Hall, Inc., Upper Saddle River, NJ. 624 pp.

Mitchell, E. 1839. Notice of the height of mountains in North Carolina. American Journal of Science and Arts 35:377-380.

Mitchell J.S., and R.W. Ruess. 2009. $\mathrm{N}_{2}$-fixing alder (Alnus viridis ssp. fruticosa) effects on soil properties across a secondary-successional chronosequence in interior Alaska. Biogeochemistry 95:215-229.

Mitchell, W.W. 1968. On the ecology of Sitka Alder in the subalpine zone of south-central Alaska. Pp. 45-56, In J.M. Trappe, J.F. Franklin, R.F. Tarrant, and G.M. Hansen (Eds.). Biology of Alder: Proceedings of a Symposium at Pullman, WA, US Department of Agriculture, Forest Service, Pacific Northwest Forest and Range Experiment Station, Portland, OR.

NatureServe. 2013. NatureServe Explorer: An online encyclopedia of life [web application]. Version 7.1. NatureServe, Arlington, VA. Available online at http://www.natureserve.org/explorer. Accessed 21 September 2013.

North Carolina Climate Retrieval and Observations Network Of the Southeast Database (NCCRONOS). 2013. NC-Cronos database. Available online at http://www.ncclimate. ncsu.edu/cronos/?station=313565. Accessed 10 September 2013.

Pawlowski, K., and W.E. Newton (Eds.). 2008. Nitrogen-fixing Actinorhizal Symbioses Series. Nitrogen Fixation: Origins, Applications, and Research Progress, Vol. 6, Springer, New York, NY. 310 pp.

Pastor, J., and D. Binkley. 1998. Nitrogen fixation and the mass balances of carbon and nitrogen in ecosystems. Biogeochemistry 43:63-78.

Pittillo, J.D., R.D. Hatcher, Jr., and S.W. Buol. 1998. Introduction to the environment and vegetation of the southern Blue Ridge province. Castanea 63:202-216.

Powell, J. 2011. Impacts of goat browsing and disease on Lilium grayi, Gray's Lily, on Roan Mountain. Honors Thesis. East Tennessee State University, Johnson City, TN. 33 pp. Available online at http://honors.epub.etsu.edu/82/. 10 September 2013.

Rhoades, C., H. Oskarsson, D. Binkley, and B. Stottlemyer. 2001. Alder (Alnus crispa) effects on soils in ecosystems of the Agashashok River valley, northwest Alaska. Ecoscience 8:89-95.

Rodgers, J. 1953. Geologic map of East Tennessee with explanatory text. Bulletin 58, Part II. Prepared by the US Geological Survey and the Tennessee Division of Geology, Department of Environment and Conservation, Nashville, TN. Republished 1993. Available online at http://www.tn.gov/environment/tdg/maps/onlinepubs.shtml. Accessed 15 July 2013.

Ross, D.S. 1995. Recommended methods for determining soil cation-exchange capacity. Recommended Soil Testing Procedures for the Northeastern United States. University of Delaware, Newark, DE. Experiment Station Bulletin no. 493:62-69.

Sampò, S., R. Bergero, G. Buffa, and A.M. Luppi-Mosca. 1997. Soil fungal communities in a young and an old Alnus viridis coenosis. Mycological Society of America 89:837-845.

SAS Institute. 2002. SAS v9.2. Cary, NC. 
Schafale, M.P. 2012. Guide to the natural communities of North Carolina: Fourth approximation. North Carolina Natural Heritage Program, Department of Natural Resources, Raleigh, NC. 217 pp.

Schulte, E.E., and B.G. Hopkins. 1996. Estimation of organic matter by weight loss-onignition. Pp. 21-31, In F.R. Magdoff, M.A. Tabatabai, and E.A. Hanlon (Eds.). Soil Organic Matter: Analysis and Interpretation. Soil Science Society of America Special Publication 46. Soil Science Society of America, Madison, WI. 67 pp.

Shoemaker, H.E., E.O. McLean, and P.F. Pratt. 1961. Buffer methods of determining lime requirements of soils with appreciable amounts of extractable aluminum. Soil Science Society of America Proceedings 25:274-277.

Stanitski, C.L., L.P. Eubanks, C.H. Middlecamp, and W.J. Stratton. 2000. Neutralizing the Threat of Acid Rain: Chemistry in Context (Third Edition). American Chemical Society. US Environmental Protection Agency. Acid rain and related programs. USEPA. Washington, DC.

Strother, J. 1799. Strother's survey diary. Pp. 35-39, In G. Ellison (Ed.) and E. Ellison (Ill.). 2008. High Vistas: An Anthology of Nature Writing from Western North Carolina and the Great Smoky Mountains. The History Press, Charleston, SC. 128 pp.

United States Department of Agriculture (USDA). 2013. Web Soil Survey, Carter Co. TN, Mitchel Co., NC. Soil Survey Report. Available online at http://websoilsurvey.sc.egov. usda.gov/App/HomePage.htm. Accessed 7 September 2013.

USDA Forest Service. 1991. Environmental assessment for vegetation management of the Roan Mountain grassy balds, Pisgah and Cherokee National Forests. Pisgah National Forest, Toecane Ranger District, Burnsville, NC. 196 pp.

USDA Forest Service. 2004. Long range management plan, Cherokee National Forest. Management Bulletin R8-MB 114A, Cleveland, TN. 471 pp.

Vitousek, P., J.R. Gosz, C.C. Grier, J.M. Melillo, W.A. Reiners. 1982. A comparative analysis of potential nitrification and nitrate mobility in forest ecosystems. Ecological Monographs 52:155-177.

Weakley, A.S. 2012. Flora of the Southern and Mid-Atlantic states. University of North Carolina Herbarium, Chapel Hill, NC. Working draft of 28 September 2012. 1229 pp.

Weigl, P.D., and T.W. Knowles. 1999. Antiquity of southern Appalachian grass balds: The role of keystone megaherbivores. In R.P. Eckerlin (Ed.). Proceedings of the Appalachian Biogeography Symposium. Virginia Museum of Natural History 7:215-224.

Wells, B.W. 1937. Southern Appalachian grass balds. Journal of the Elisha Mitchell Society 53(1):1-26.

Wherry, E.T. 1960. Intermediate occurrences of Alnus crispa. Castanea 25:135.

White, P.S., S.P. Wilds, and D.A. Stratton. 2001. The distribution of the heath balds in the Great Smoky Mountains, North Carolina and Tennessee. Journal of Vegetation Science. 12:453-466.

Wurzburger, N., and R.L. Hendrick. 2007. Rhododendron thickets alter N-cycling and soil extracellular-enzyme activities in southern Appalachian hardwood forests. Pedobiologia 50:563-576. 